\title{
A New Project-Based Learning in English Writing
}

\author{
https://doi.org/10.3991/ijet.v16i05.21271 \\ Qiaohua Lu \\ Guangxi Normal University, Guilin, China \\ janelu82637@sina.com
}

\begin{abstract}
At present, more international talents are needed. English writing ability is an essential quality for such talents. However, by far the teaching of English writing is faced with some problems, that is, students lack interest and learn passively, teachers' teaching methods are not diversified enough, and there are insufficient interactions between teachers and students in the classroom. How to improve the effectiveness of the teaching of English writing has become a top priority in the current teaching reform of English writing. By taking advantage of Internet information technology, this study establishes an online teaching mode for English writing. In view of the characteristics of the teaching of English writing, based on the classroom design concept of ADDIE (Analysis, Design, Development, Implementation and Evaluation). In the meantime, by integrating the project-based learning mode, we assign writing project questions and incorporate such steps as information collection, knowledge acquisition, solution discussion, peer collaboration, hands-on practice, etc. On the other hand, the neural network algorithm is also used to classify texts of electronic lecture notes. It is found through teaching practice, that the project-based learning based on the concept of ADDIE is an effective teaching way, which can significantly improve the effect of classroom teaching and enhance students' learning initiative.
\end{abstract}

Keywords-ADDIE; project-based learning; English writing; data mining

\section{Introduction}

Since the inception of economic globalization, various countries have developed their economies at a high speed. Nowadays, with the acceleration of internationalization in all walks of life, a huge demand has emerged for international talents. English, as an important language for international communication, has become a primary and essential quality of international talents [1]. As the last period before students step into society, the English proficiency of students plays a very significant role in their future development. The most critical part in the training of English skills is English expression skills, which not only includes oral expression, but also incorporates English writing ability. For this reason, in college English teaching, attention should be paid to the improvement of students' English writing ability [2]. Although the course of English writing has been offered in universities, the job market has put forward increasingly higher requirements for graduates' English 
expression ability in the new era, which poses a great challenge to college English writing. In addition, many schools haven't attached much importance to this course, their teaching methods are monotonous, and students' learning initiative is not strong enough. All of these greatly diminish the teaching effect of college English writing [3].

As a matter of fact, with the rapid development of information technology, schools have vigorously advanced the informationization of education. How to actively propel the development of "Internet+ education" and effectively improve the teaching efficiency by applying Internet information technology has become a vital task of the educational circles at the current stage. The teaching concept of ADDIE, as a method based on Internet information technology, has been favored by many colleges [4]. It mainly covers five stages, including analysis, design, development, implementation and evaluation. These five parts, which are interrelated and influenced by each other, constitute a dynamic circulation pattern [5]. On this basis, with an eye to effectively enhance the teaching effect of English Writing, this paper analyzes the application and practice of project-based learning in the course of English Writing based on the concept of ADDIE.

There are three innovation points in the research of this paper. First of all, so far, there are many studies on the application of the concept of ADDIE in education, but there are very few studies on its application in the teaching of English writing. Secondly, our study fully merges the concept of project-based learning and launch inquiry learning with project questions. Thirdly, in consideration of the rapid development of Internet information technology, the concept of ADDIE is also applied to online English writing class. With the intention of enhancing the efficiency of online English writing class, this paper also analyzes the electronic lecture notes of online English class using neural network analysis, in the hope of providing a reference for the writing courses of relevant languages.

\section{State of the Art}

Scholars have done a lot of research on non native language teaching. Lee \& Wallace [6], for example, focused on the application of flipped classroom in the teaching of non native language writing. On the one hand, the author acknowledged the importance of flipped classroom for improving English writing. On the other hand, he also employed error analysis, analyzed the total scores of students in English writing and accurate use of vocabulary, etc., through accuracy, to further verify the effectiveness of flipped classroom in the teaching of English writing. Karoly et al. [7] suggested using functionalist theoretical framework to teach English, namely, after a pre-translation source text analysis of three texts with EU topics, data were collected by two methods: a linguistic analysis of the student translations of these texts to identify and analyze the most common translation problems, and semi-structured interviews to explore their individual difficulties. The results showed that this teaching mode can better raise students' academic performance. Er [8] suggested applying total physical response (TPR) to teenagers' English learning. TPR was an 
approach based on the coordination between speech and behavior. There was no text in the teaching environment. Instead, teaching was carried out in the form of songs, games and stories. The results showed that this teaching approach can well attract students' attention. Bajorek \& Gawroński [9] applied new media to English teaching and held that mass media, especially new media, were an important tool not only in the self-education process of English teachers, but also for English teachers. They stressed that technological progress, communication revolution, popularization of Internet and development of new media and mobile technology offered modern and effective ways to teach language.

With an eye to improve the effect of college English courses, many Chinese scholars carried out different studies on college English courses. For example, Wu et al. [10] probed into the application of the mixed teaching mode of online teaching and traditional classroom instruction in the course of college students' English reading. The results indicated that the proposed mixed teaching mode can effectively enhance students' learning efficiency, especially the methods of online teaching, offline discussion and diversified assessment. They greatly enhanced students' interest in learning English. Wang [11] examined the application of theme-based teaching in college English reading and considered that theme-based teaching fully merged topdown theory and bottom-up theory. It blended practice with reading theory, can effectively promote students' interest and ability of reading, and was of great significance for the improvement of college students' ability to use language. Jia [12] emphatically analysed the application of mind mapping in college English intensive reading and assumed that that mind mapping can provide train of thought and ideas for students' English learning, help students have a quick command of knowledge points and help them get down to reading quickly. Xia [13] investigated the application of micro-class in college English viewing, listening and speaking class, believing that micro-class not only optimized the drawbacks of college viewing, listening and speaking class and raised students' interest in English learning, but also improved the teaching effect of English class. She argued that micro-class should be fully utilized in lesson preparation, classroom explanation and after-class evaluation of college English. A fraction of scholars have done research on the application of the concept of ADDIE in college English. Dunlap et al. [14] set up an online learning community for college English from five aspects: analysis, design, development, implementation and evaluation, with a view to realize the writing communication, knowledge sharing and reciprocal learning of English and effectively enhance the online teaching effect of college English.

By summarizing the above-mentioned research, we can see that many domestic and foreign scholars have carried out research on English teaching and college English teaching. Therein, with respect to the teaching methods of the course, scholars have also come up with many methods. Some of these methods are traditional, some are "Internet plus" teaching methods, while some fully merge two teaching methods. But generally speaking, these teaching methods are not innovative enough and the evaluation of teaching effect is too subjective. Few studies have been reported on the application of the concept of ADDIE in college English, especially in college English writing. On this account, this paper aims to investigate the application 
of the concept of ADDIE in college English writing, in combination with projectbased learning mode.

\section{Project-Based Learning Mode Based on ADDIE}

\subsection{Project-based learning in the teaching of English writing}

According to relevant theory by William Kilpatrick [15], English writing can be regarded as a project, in which students should be immersed whole-heartedly. For students, English writing was initially a complex and unfamiliar challenge. But after learning for a period, students can gradually master key knowledge and skills in it. This process was known as project-based learning. The teaching strategies of projectbased learning are divided into three aspects: target setting, teaching content integration, encouragement, comment and feedback. To be specific, the application route of project-based learning in the teaching of English writing is shown in Fig. 1 below:

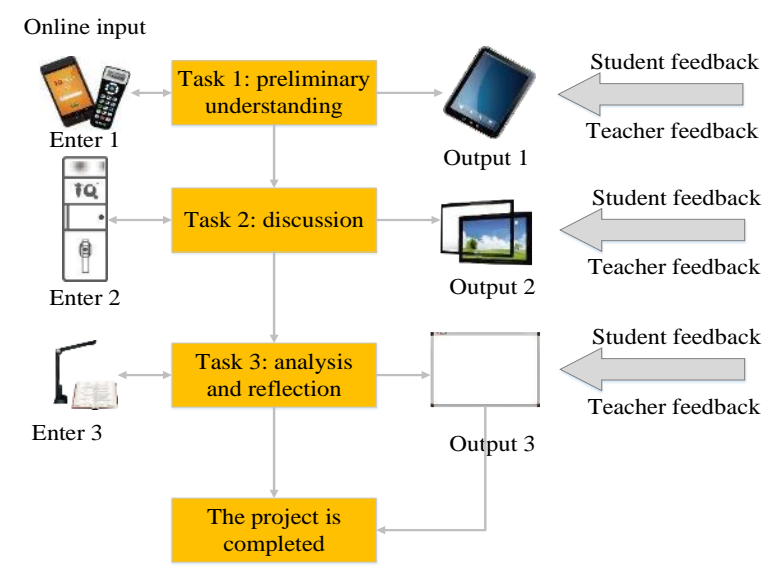

Fig. 1. The Application Route of Project-based Learning in the Teaching of English Writing

First of all, while applying the teaching strategies of project-based learning, English teachers should help students set a target. This is also the core of the teaching strategies of project-based learning. To be specific, English teachers are supposed to encourage students to gain a preliminary understanding of the writing topic and capture the key points therein. If students capture key points that are irrelevant to the topic, English teachers can keep the teaching rolling on by not making any comment or asking other students instead, to make the students give up irrelevant key points inadvertently.

Secondly, when applying the teaching strategies of project-based learning, English teachers and students should consolidate the teaching content. On the one hand, 
English teachers should consolidate relevant teaching content in the teaching of English writing. They should also direct students to deeply discuss key points extracted, gradually refine these key points and transform them into questions that are acceptable to students. For example, in English writing, there are often some topics that are unfamiliar to students, for which English teachers are supposed to guide them to deeply discuss their close connection with these topics. On the other hand, students should consolidate and analyze information in view of their own questions and summarize relevant English writing skills. In order to effectively promote the teaching effect of English writing, for each stage English teachers help students set a target, students should be encouraged to record the results.

Finally, when applying the teaching strategies of project-based learning, English teachers and students should also handle the comments and feedback properly. To be specific, this includes three aspects. First of all, English teachers are supposed to evaluate students' extraction of key points, deep discussion, analysis and reflection process, as well as the writing content they form. Secondly, students should give timely feedback on the difficulties and queries they encounter in the extraction of key points, deep discussion, analysis and reflection process, as well as comments made by teachers. Thirdly, teachers should give feedback on difficulties proposed by students.

Through the above route, after repeated teaching, students gradually acquire knowledge and skills in English writing, and thereby the teaching project of English writing is completed successfully.

\subsection{Electronic text classification based on neural network in the course of English writing}

In the teaching of English writing based on project-based learning, after a preliminary understanding of the writing topic, it is a very crucial step to extract key points of the writing topic, which can be achieved by subjective judgment. However, the application of this method requires rich experience in summarization and has strong subjectivity. In view of this, in the teaching of English writing, it is necessary to introduce more scientific text classification method. At present, electronic text classification based on neural network is a commonly used method. The target setting in the teaching of English writing based on neural network is precisely to minimize expected loss in a given sample set. To be specific:

$$
E \quad\left(J \quad\left(w, b ; x, y^{*}\right)\right)=\int_{x} J \quad\left(w, b ; x, y^{*}\right) p(x) d(x)
$$

Where $w$ is the weight of the neural network, $b$ is the bias of the neural network, $x$ is the actual input of the neural network, and also specific samples. $y^{*}$ is the expected output of samples. $J\left(w, b ; x, y^{*}\right)$ can measure the difference between the actual output $y$ and the expected output $y^{*} \cdot p(x)$ is the probability density function of samples.

For the purpose of improving the application effect of the neural network in the teaching of English writing, we need to conduct constraint solution on the loss function of Eq. (1) by adding a regularization term as follows:

$$
J\left(w, b ; x, y^{*}\right)+R(w)
$$


Where $R(w)$ is the elastic network model of the regularization term, which can be expressed as:

$$
R(w)=\lambda_{1}^{*} \sum_{i=1}^{n}\left(\left|w_{i}^{*}\right|+\varepsilon\right)^{-\gamma}\left|w_{i}\right|+\lambda_{2} \sum_{i=1}^{n} w_{i}^{2}
$$

Where $\varepsilon$ is mainly intended to prevent the denominator from being 0 , while $w_{i}^{*}$ is the parameter optimization result of the elastic network model of the regularization term. In combination with Eqs. (2) and (3), the optimization model for the projectbased learning of English writing based on neural network can be integrated as:

$$
J\left(w, b ; x, y^{*}\right)+\lambda_{1}^{*} \sum_{i=1}^{n}\left(\left|w_{i}^{*}\right|+\varepsilon\right)^{-\gamma}\left|w_{i}\right|+\lambda_{2} \sum_{i=1}^{n} w_{i}^{2}
$$

The data set $(\mathrm{X}, \mathrm{Y})$ is put into the learning optimization model of Eq. (4), the parameters of the elastic network model can be obtained by minimizing the loss. After that, an elastic network is established according to Eq. (3). Then according to Eq. (4), a new learning optimization model can be built and re-iterated.

Rectified linear units are used to prevent the phenomenon of vanishing gradient in back propagation, that is:

$$
f(x)=\max (0, x)
$$

In this way, the forward computation of a neural network is exactly the regression of a linear regression model. The expected loss minimization model can be transformed into:

$$
\widetilde{w}^{*}=\arg _{w} \min \left(\left|Y-X w_{c^{l-1} * c^{l}}\right|^{2}+\lambda_{1}^{*} \sum_{j=1}^{c^{l-1} * c^{l}} \widehat{w}\left|w_{j}\right|+\lambda_{2} \sum_{j=1}^{c^{l-1} * c^{l}} w_{j}^{2}\right)
$$

Considering the possibility of e some anomalies in the input term X, it is necessary to modify it. The modified optimization goal of English writing learning can be transformed into:

$$
\widetilde{w}^{*}=\arg _{w} \min \left(\left|Y^{*}-X^{*} w_{c^{l-1} * c^{l}}\right|^{2}+\lambda_{1}^{*} \sum_{j=1}^{c^{l-1} * c^{l}} \widehat{w}\left|w_{j}\right|+\lambda_{2} \sum_{j=1}^{c^{l-1} * c^{l}} w_{j}^{2}\right)
$$

Where $\left(X^{*}, Y^{*}\right)$ is the data set after modification. To be specific, $X^{*}=\left(\begin{array}{c}X \\ \sqrt{\lambda_{2} I}\end{array}\right)$, $Y^{*}=\left(\begin{array}{l}Y \\ 0\end{array}\right)$. In fact, according to the KKT conditions, the data set $\left(X^{*}, Y^{*}\right)$ can be transformed into:

$$
2 X_{j}^{* T}\left(Y^{*}-X^{*} \widetilde{w}^{*}\right)=\lambda_{1}^{*} \widehat{w}_{j},
$$

$X_{j}^{*}{ }^{T}$ in Eq. (8) is an attribute vector corresponding to the weight $\widetilde{w}^{*}$ in all sample sets. According to the nature of Oracle, Eq. (8) can be further refined as:

$$
\frac{2}{\sqrt{n}} X_{j}^{*},{ }^{T}\left(\varepsilon^{*}+X^{*} \widetilde{w}-X^{*} \widetilde{w}^{*}\right)=2\left(\frac{X_{j}^{*}{ }^{T} X^{*} \sqrt{n}\left(\widetilde{w}-\widetilde{w}^{*}\right.}{n}+\frac{X_{j}^{*}{ }^{T} \varepsilon^{*}}{\sqrt{n}}\right)
$$

Combined with the group selection ability, the expected loss minimization model can be converted into: 


$$
\widetilde{w}^{*}=\arg _{w} \min L\left(\lambda_{1}^{*}, \lambda_{2}, w\right)(10)
$$

$L$ finds partial derivative for $\widetilde{w}_{i}^{*}$ and $\widetilde{w}_{j}^{*}$ respectively. And after further sorting, we can get:

$$
\lambda_{2}\left|\widetilde{w}_{i}^{*}-\widetilde{w}_{j}^{*}\right|=\left|\left(X_{i}^{T}-X_{j}^{T}\right) \quad\left(Y-X \widetilde{w}^{*}\right)-\frac{\lambda_{i}^{*}}{2}\left(\widehat{w}_{i}-\widehat{w}_{j}\right) \operatorname{sgn}\left(\widetilde{w}_{i}^{*}\right)\right|
$$

When the above model is applied to the teaching of English writing, electronic texts of English writing topics can be classified, to facilitate the extraction of keywords. To be specific, in the classification process of electronic lecture notes of online English class, the classification can be divided into 8 steps, that is, data sorting, manual annotation, data pre-processing, word2Vec word embedding, data sampling, model training and model adjustment. The details are shown in Fig. 2 below:

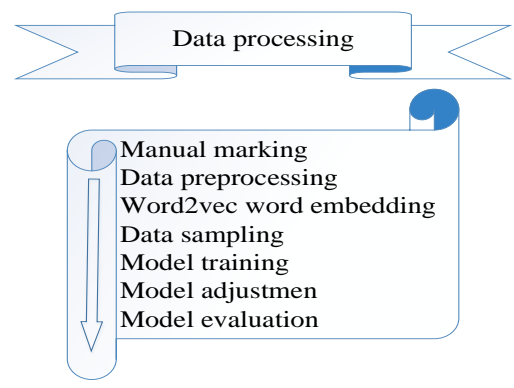

Fig. 2. Classification Process of Electronic Lecture Notes of Online English Class

Based on the above model, a total of 36 people were invited to attend an online English class, who were divided into 9 groups, with 4 people in each group. For each group, the learning content of online course and learning task were the same. The learning lasted 2 hours. During the learning, 9 groups produced a total of 5,608 interaction texts, an average of 623 in each group. After that, the author trained and tested the resulting data, of which $20 \%$ were taken as the test set and $80 \%$ as training set. In addition, accuracy rate, F1 value, recall rate and precision rate were taken as evaluation indicators of the classification of electronic lecture notes of online English class. The evaluation data obtained using the above model are shown in Tab. 1 below:

Table 1. Experiment Results of Classification

\begin{tabular}{|l|c|}
\hline \multicolumn{1}{|c|}{ Evaluation Indicator } & Evaluation Result \\
\hline Accuracy Rate & 81.34 \\
\hline F1 Value & 77.98 \\
\hline Recall Rate & 86.05 \\
\hline Precision Rate & 70.02 \\
\hline
\end{tabular}

From above, the accuracy rate of the electronic text classification model based on neural network was relatively high, so the proposed model was conducive to the 
classification of electronic lecture notes of online English class, which enabled teachers not only to quickly understand the speech characteristics, behaviour characteristics, interaction mode and progress of students, but also to capture the emotional tendency and knowledge construction mode of students when reviewing lecture notes.

\subsection{English writing course based on the teaching concept of ADDIE}

So far, with the rapid development of information technology, intelligent teaching mode has been widely favoured by the educational circles. Therein, the teaching concept of ADDIE is a commonly used one, which can also be applied to the course of English writing. ADDIE [15] refers to a set of methods used to develop teaching systematically, mainly including: what to learn (the setting of a learning target); how to learn (the use of learning strategies) and how to judge whether the learners have achieved the expected outcome (the implementation of learning assessment). Among the five stages of ADDIE, analysis and design are the premise, development and implementation are the core, and evaluation is the warranty. The three are interrelated and inextricably bound up. The five letters of ADDIE stand for analysis, design, develop, implement and evaluate respectively. The details are shown in Fig. 3 below:

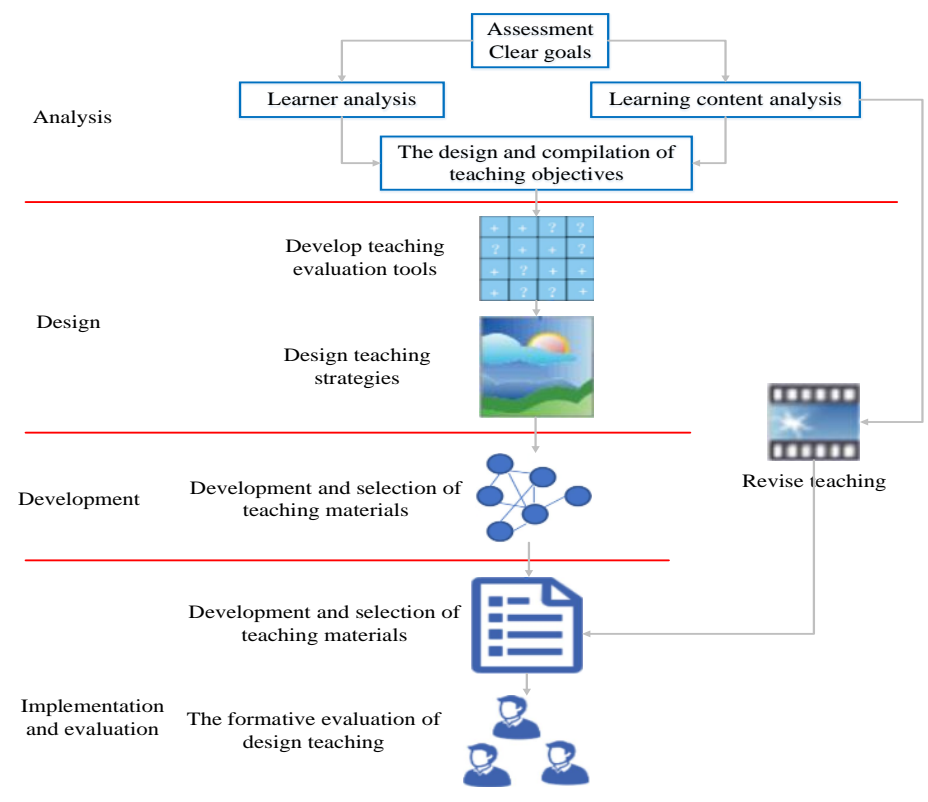

Fig. 3. The Framework of the Teaching Concept of ADDIE

According to Fig. 3 above, the teaching concept of ADDIE is infused in English writing. To be specific, it can be carried out in the following way:

Analysis stage: This stage requires pre-setting and determining the teaching objectives of the course of English writing. At the same time, it also requires 
specifying the teaching objectives as far as possible. The presetting of teaching objectives means that English teachers should preset teaching objectives for English writing, combined with the standard teaching objectives of the course, to improve students' English writing ability. In order to set teaching objectives, English teachers need to identify teaching objectives for the English writing course from three dimensions: knowledge and skills, emotional attitudes and values, processes and methods. For example, in terms of knowledge and skills, English teachers should set grammar, word order and other knowledge and skills that students are supposed to acquire. Processes and methods are to help students to develop ideas of English writing, while attitudes and values are to help students form correct values and outlook on life, while improving their English writing ability. By analyzing learners and learning contents, we finally determined the teaching objectives of English writing.

Design stage: This stage requires English teachers to design an English writing teaching strategy that is fit for implementation, according to the conditions of students. To be specific, this includes four aspects: student description, choice of transmission system, design of teaching content and design of teaching process. Therein, student description and choice of transmission system are evaluation tools, while the design of teaching content and design of teaching process are development of teaching strategies. In addition to observing and evaluating students through traditional classroom instruction, student description should also be combined with information technology, to gain a deeper insight into students' reactions in English writing class. The choice of transmission system requires English teachers to make full use of all kinds of information technologies in the teaching of English writing. On this basis, English teachers are supposed to develop teaching content and teaching process. For example, they need to design learning objectives, learning process, important and difficult points in teaching content, in accordance with the objectives designed in the analysis stage, take students as the subject as far as possible and improve students' autonomy in English writing class.

Development stage: This stage is mainly for English teachers to develop and select teaching materials for English writing, such as the teaching resources, teaching aids, teaching courseware, etc. selected by teachers. Simultaneously, to understand students' English writing ability and observe the promoting effect of the course of English writing on students' writing ability, English teachers should also develop assessment tools, such as classroom exercise, exam papers and classroom observation forms, etc. Typically, whether English teachers are well prepared or not in the development stage directly influences the teaching effect of English writing. The development scenario of the teaching concept of ADDIE in the course of English writing is shown in Fig. 4.

Implementation and evaluation: This stage is mainly for English teachers to teach English writing based on the above-mentioned analysis results, design and development. In the meantime, to effectively understand the teaching quality of English writing, it is also needed to evaluate the application effect of the teaching concept of ADDIE in the teaching of English writing. Such kind of evaluation includes formative evaluation and summative evaluation. Formative evaluation 
requires evaluating the whole teaching process, from teaching design, choice of teaching materials to teaching implementation, etc. This assessment can help discover the deficiencies of the teaching concept of ADDIE in each stage of the teaching of English writing. While summative evaluation is to evaluate the teaching effect of English writing, in order to judge whether it is necessary to teach English writing with the teaching concept of ADDIE. The application scenario of the teaching concept of ADDIE in the course of English writing is shown in Fig. 5. It mainly belongs to the stage of implementation and evaluation.

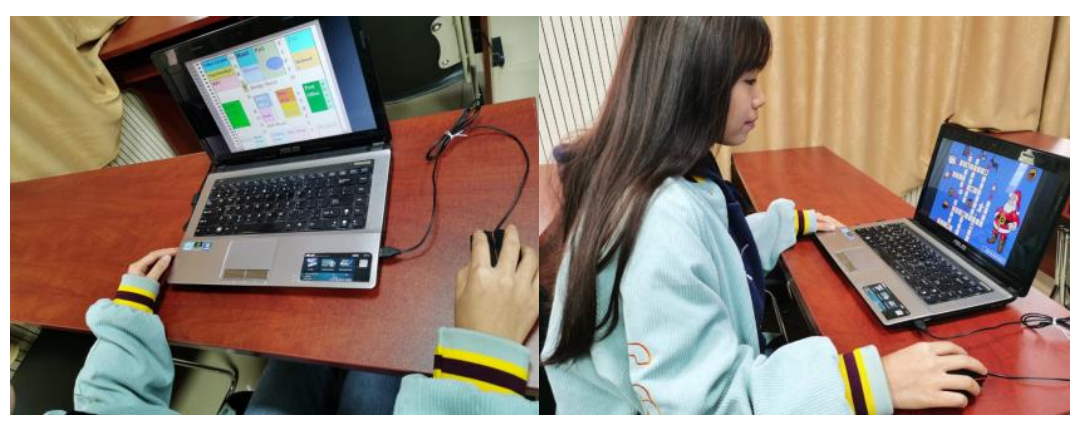

Fig. 4. The Development Stage of the Teaching Concept of ADDIE in English Writing

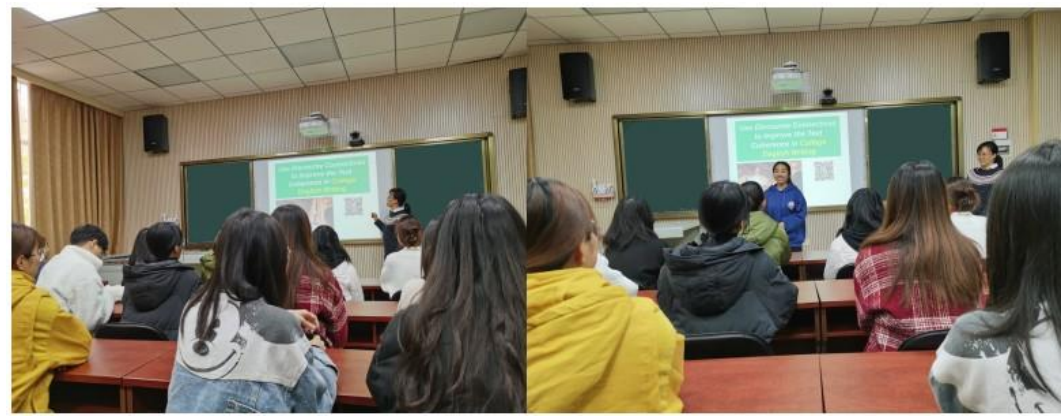

Fig. 5. The Implementation and Evaluation of the Teaching Concept of ADDIE in English Writing

\section{$4 \quad$ Teaching Example and Effect}

\subsection{Teaching example}

Using the teaching concept of ADDIE, the teaching mode of English writing can be designed as follows, as shown in Tab. 2: 
Table 2. The Teaching of English Writing Based on the Teaching Concept of ADDIE

\begin{tabular}{|c|c|c|}
\hline Stage & Task Design & Specific Mode \\
\hline \multirow{4}{*}{ Analysis } & $\begin{array}{l}\text { To analyze the teaching } \\
\text { objects }\end{array}$ & $\begin{array}{l}\text { Knowledge reserve, learning habits and learning ability } \\
\text { of teaching objects. }\end{array}$ \\
\hline & $\begin{array}{l}\text { To analyze the teaching } \\
\text { objectives }\end{array}$ & $\begin{array}{l}\text { Standard teaching objectives, general teaching } \\
\text { objectives, teaching objectives of English writing }\end{array}$ \\
\hline & $\begin{array}{l}\text { To analyze the teaching } \\
\text { content }\end{array}$ & $\begin{array}{l}\text { Knowledge architecture and its relationship with other } \\
\text { knowledge }\end{array}$ \\
\hline & $\begin{array}{l}\text { To analyze the teaching } \\
\text { environment }\end{array}$ & $\begin{array}{l}\text { Classroom teaching environment, online learning } \\
\text { environment }\end{array}$ \\
\hline \multirow{3}{*}{ Design } & $\begin{array}{l}\text { To determine the teaching } \\
\text { mode }\end{array}$ & Online+ offline teaching mode \\
\hline & To choose teaching strategies & $\begin{array}{l}\text { Teaching organization strategy, teaching transmission } \\
\text { mode and teaching management strategy }\end{array}$ \\
\hline & $\begin{array}{l}\text { To design the teaching } \\
\text { process }\end{array}$ & $\begin{array}{l}\text { The design of local teaching process and global } \\
\text { teaching process }\end{array}$ \\
\hline \multirow{2}{*}{ Development } & $\begin{array}{l}\text { To design classroom teaching } \\
\text { tasks }\end{array}$ & $\begin{array}{l}\text { Teaching courseware, teaching materials, classroom } \\
\text { exercise and exam papers, etc. }\end{array}$ \\
\hline & $\begin{array}{l}\text { To design online classroom } \\
\text { teaching }\end{array}$ & $\begin{array}{l}\text { Video materials, teaching courseware and classroom } \\
\text { exercise, etc. }\end{array}$ \\
\hline \multirow{3}{*}{$\begin{array}{l}\text { Implementation and } \\
\text { Evaluation }\end{array}$} & $\begin{array}{l}\text { To implement teaching } \\
\text { activities }\end{array}$ & $\begin{array}{l}\text { The implementation of online teaching and classroom } \\
\text { teaching. }\end{array}$ \\
\hline & Formative evaluation & Periodical tests and classroom observation, etc. \\
\hline & Summative evaluation & $\begin{array}{l}\text { English writing proficiency test and the report on the } \\
\text { variation of English writing proficiency. }\end{array}$ \\
\hline
\end{tabular}

Among them, classroom teaching was a traditional teaching way, so it would be more acceptable for English teachers to teach English writing based on ADDIE teaching concept. However, due to the need to use advanced information technology in online classroom teaching, it was difficult for English teachers to set about the specific design, development and implementation. For this reason, this paper expounded on the online teaching mode of English writing based on the teaching concept of ADDIE. The details are shown in Tab. 3 below:

Table 3. The Online Teaching Mode of English Writing Based on the Teaching Concept of ADDIE

\begin{tabular}{|l|l|}
\hline \multicolumn{1}{|c|}{ Stage } & \multicolumn{1}{c|}{ Specific Mode } \\
\hline Analysis & Course orientation, teaching calendar, learning objectives, etc. \\
\hline \multirow{3}{*}{ Design } & To design a learning roadmap and a learning task map \\
\cline { 2 - 3 } & $\begin{array}{l}\text { To design a list of unit knowledge and design the teaching content of each type of English } \\
\text { writing topic }\end{array}$ \\
\hline \multirow{3}{*}{ Development } & $\begin{array}{l}\text { Video teaching materials: micro videos for theoretical teaching, micro videos for exercise } \\
\text { teaching }\end{array}$ \\
\cline { 2 - 3 } $\begin{array}{l}\text { Implementation } \\
\text { and Evaluation }\end{array}$ & $\begin{array}{l}\text { Other teaching resources: teaching courseware, auxiliary teaching materials, e-books and } \\
\text { English movies, etc. }\end{array}$ \\
\cline { 2 - 3 } & $\begin{array}{l}\text { To implement online teaching. } \\
\text { English writing proficiency test and the report on the variation of English writing } \\
\text { proficiency. }\end{array}$ \\
\hline
\end{tabular}




\subsection{Teaching effect}

To verify the effectiveness of the English writing teaching mode shown in Tabs. 2 and 3, the author carried out a test. The teaching of English writing in University A in the second semester from 2019 to 2020 was taken as an example. To be specific, this author selected 4 classes, A1, A2, A3 and A4, with 36, 35, 32 and 37 students in each class. Among them, Classes A1 and A2 were the experimental groups and received English writing instruction based on the teaching concept of ADDIE. While Classes A3 and A4 were the control groups and received English writing instruction according to the previous practice. SPSS analysis software was used to analyze the integrated scores and English writing scores of the experimental groups and control groups, as shown in Tab. 4 below:

Table 4. Analysis of Students Scores

\begin{tabular}{|l|c|c|c|c|}
\hline \multirow{2}{*}{\multicolumn{1}{|c|}{ Group }} & \multicolumn{2}{c|}{ Integrated Score } & \multicolumn{2}{c|}{ Writing Score } \\
\cline { 2 - 5 } & $\begin{array}{c}\text { Before } \\
\text { intervention }\end{array}$ & $\begin{array}{c}\text { After } \\
\text { intervention }\end{array}$ & $\begin{array}{c}\text { Before } \\
\text { intervention }\end{array}$ & $\begin{array}{c}\text { After } \\
\text { intervention }\end{array}$ \\
\hline Experimental Groups $(\mathrm{n}=71)$ & $79.34 \pm 3.23$ & $87.15 \pm 4.10$ & $75.33 \pm 3.62$ & $91.80 \pm 4.18$ \\
\hline Control Groups $(\mathrm{n}=69)$ & $78.11 \pm 4.28$ & $80.16 \pm 5.17$ & $76.07 \pm 5.02$ & $77.74 \pm 3.29$ \\
\hline $\mathrm{T}$ & 0.791 & 1.698 & 0.611 & 1.892 \\
\hline $\mathrm{P}$ & 0.287 & 0.019 & 0.329 & 0.000 \\
\hline
\end{tabular}

An analysis of students' scores shown in Tab. 4 showed that at a significant level of 5\%, there was no significant difference between the experimental groups and the control groups in terms of integrated score and writing score before the teaching of English writing based on the teaching concept of ADDIE. After the application of the teaching concept of ADDIE to the teaching of English writing in the experimental groups, however, the integrated score and writing score of the experimental groups were significantly improved, compared with the control groups that didn't adopt the teaching concept of ADDIE. The improvement of writing score was more dramatic and difference was more evident, which suggested that the concept of ADDIE can significantly improve the teaching effect of college English writing, and the concept of ADDIE should be fully capitalized in the teaching of college English writing. First of all, in the learning process of English writing, the online learning space created by the concept of ADDIE can offer high-quality resource services. Teachers can link Internet resources to such learning space, so that students can query and use easily and improve their academic performance. Secondly, the learning space based on ADDIE theory can record the whole learning process. Teachers and students can upload their own learning activities to this space in a timely manner to increase teacher-student interaction, which was beneficial to students' understanding of knowledge. Thirdly, learning activities would produce corresponding data and offer a ground for learning assessment, so that teachers can keep abreast of students' learning. They can bring convenience to communication, sharing and remote cooperation in the learning process and further improve students' English writing skills. 


\section{Conclusion}

This paper emphatically analyses the application of project-based learning based on the concept of ADDIE in college English writing. By dissecting the application mode of project-based learning and the concept of ADDIE in the course of English writing and combining with the analysis of a specific example, this paper verifies the important role of the teaching concept of ADDIE in the teaching of English writing. And the following conclusion is drawn:

1. The teaching of English Writing should be approached in the form of project-based learning. English teachers should facilitate the completion of the English writing project through target setting, teaching content integration, encouragement, comment and feedback, help students gradually refine their questions and acquire writing knowledge and skills.

2. The electronic text classification based on neural network is of great significance for online learning of college English Writing. Thanks to it, the electronic text classification in the course of English writing is no longer the traditional manual one, but a more scientific one. With this method, both the precision and accuracy can be above $70 \%$.

3. The teaching concept of ADDIE, that is, four stages of analysis, design, development, implementation and evaluation, can not only be applied to the teaching of traditional college English Writing, but also applied in the online teaching of English writing. The analysis results of specific example show that this teaching concept can significantly improve students' integrated score and writing score, which indicates that the teaching concept of ADDIE is of great significance for improving the effectiveness of English writing.

However, there are also some shortcomings in this study. For example, with the rapid development of information technology, currently, in addition to the teaching concept of ADDIE, many other advanced teaching concepts have also been applied to the teaching of English writing. And whether the teaching concept of ADDIE is the most effective and simplest way still needs further comparison.

\section{References}

[1] Sun, R., Zhang, H., Li, J., et al. Assessment-for-Learning Teaching Mode Based on Interactive Teaching Approach in College English. International Journal of Emerging Technologies in Learning, 2020, vol. 15(21), pp. 24-39. https://doi.org/10.3991/ijet.v15i21. $\underline{18029}$

[2] Kim E J , Lee E J . The effects of c orpus-based formulaic sequences learning on high school students' English writing ability and attitudes. Foreign Languages Education, 2020, vol. 27(4), pp. 119-143. https://doi.org/10.15334/FLE.2020.27.4.119

[3] Zhang, X., Wang, S., Cao, Y., et al. Application of Analytical Hierarchy Process in Teaching Quality Analysis of English Writing. International Journal of Emerging Technologies in Learning, 2020, vol. 15(14), pp. 137-150. https://doi.org/10.3991/ijet.v15i $\underline{14.15359}$ 
[4] Allen, W.C. Overview and evolution of the ADDIE training system. Advances in Developing Human Resources, 2006, vol. 8(4), pp. 430-441. https://doi.org/10.1177/1523 $\underline{422306292942}$

[5] Ghani, M.T.A., \& Daud, W.A.A.W. Adaptation of ADDIE instructional model in developing educational website for language learning. Global Journal Al-Thaqafah, 2018, vol. 8(2), pp. 7-16.

[6] Lee, G., \& Wallace, A. Flipped learning in the English as a foreign language classroom: Outcomes and perceptions. Tesol Quarterly, 2018, vol. 52(1), pp. 62-84. https://doi.org/10. $1002 /$ tesq. 372

[7] Karoly, A. Translation in foreign language teaching: A case study from a functional perspective. Linguistics and Education, 2014, vol. 25, pp. 90-107. https://doi.org/10.1016/ j.linged.2013.09.009

[8] Er, S. Using Total Physical Response Method in Early Childhood Foreign Language Teaching Environments. Procedia - Social and Behavioural Sciences, 2013, vol. 93, pp. 1766-1768. https://doi.org/10.1016/j.sbspro.2013.10.113

[9] Bajorek, K., \& Gawroński, S. The use of the educational function of media in foreign language teaching. Social Communication, 2018, vol. 4(1), pp. 48-57. https://doi.org/10.24 $\underline{78 / \mathrm{sc}-2018-0006}$

[10] Wu, Z., Guo, Y., \& Wei, L. The Application of a Mixed Teaching Model to the Academic English Teaching for Graduate Students at Inner Mongolia University. Creative Education, 2020, vol. 11(2), pp. 105. https://doi.org/10.4236/ce.2020.112008

[11] Wang, X.L. Theme-based College English Teaching Model in the Light of Whole Language Approach Under Multi-media and Network Environment. Journal of Heilongjiang University of Technology, 2013, vol. 13(3), pp. 90-92.

[12] Jia, H. Application of Mind Map in the Network College English Teaching. Journal of Changchun Normal University (Humanities and Social Sciences), 2014, vol. 33(2), pp. 169-171.

[13] Xia, J. Analysis of the application value of micro lecture in College English Viewing, listening and speaking flipped classroom. English Square, 2020, vol. 111(3), pp. 39-40.

[14] Zhang, J.F. The construction of College English online learning community based on Addie model. Journal of Higher Education, 2020, vol. 153(31), pp. 102-105.

[15] Dunlap, G., Iovannone, R., Wilson, K. J., et al. (2010). Prevent-Teach-Reinforce: A standardized model of school-based behavioural intervention. Journal of Positive Behaviour Interventions, 2010, vol. 12(1), pp. 9-22 . https://doi.org/10.1177/1098300708 $\underline{330880}$

\section{Author}

Qiaohua Lu is a Lecturer in the Lijiang College, Guangxi Normal University, Guilin, China (janelu82637@ sina.com).

Article submitted 2021-01-17. Resubmitted 2021-02-23. Final acceptance 2021-02-24. Final version published as submitted by the authors. 